\title{
THEORETICAL BASIS OF DESIGN AND PRODUCTION OF MARINE ROBOTICS
}

\section{Blintsov V. S., Babkin G. V.}

\section{INTRODUCTION}

According to the estimates of the scientists engaging in World Ocean explorations (researches), its depths are explored, according to various estimates, only by $2-5$ percent ${ }^{1,2,3}$. Moreover, the most actively studied and used are only the shelf zones, where economic activities related to the extraction of useful energy and food products are actively conducted.

Currently, the implementation of underwater research work and shelf development is not possible without the use of modern marine robotics tools (MRT), which include unmanned surface vessels and underwater vehicles-robots ${ }^{4}$. Based on the research results in the field of creating MRT of different purposes, it can be concluded that unmanned underwater vehicles and systems on their bases are the most effective for performing underwater inspection and scientific missions. The relevance intensification of this conclusion is the increasing need for this type of MRTs for monitoring environmental status, underwater archaeological research, underwater search and rescue robots, etc. To perform such operations, it is projected that tens and hundreds of MRTs for underwater applications will be required.

1 How much of the ocean have we explored? URL : https://oceanservice.noaa.gov/facts/exploration.html.

${ }^{2}$ Ocean exploration. Highlights of National Academies Reports. Ocean science series. The National Academies. Advisers to the Nation on Science, Engineering and Medicine. URL : https://www.nap.edu/resource/11902/exploration_final.pdf.

${ }^{3}$ Исследования Мирового океана как шаг на пути к устойчивому развитию человечества. URL : https://rg.ru/2020/07/28/issledovaniia-mirovogo-okeana-kakshag-na-puti-k-razvitiiu-chelovechestva.html.

${ }^{4}$ Future Needs in Deep Submergence Science (2004). Occupied and Unoccupied Vehicles in Basic Ocean Research. The National Academies Press. Washington, D.C. URL : https://www.nap.edu/catalog/10854/future-needs-in-deep-submergencescience-occupied-and-unoccupied-vehicles. 
World practice shows that the MRT creation process is quite complex and science-intensive $e^{5,6,7}$. Each newly created sample of such equipment requires a number of studies related to the need to achieving high performance indicators and taking into account the operation conditions. In most cases, each MRT sample is a unique technical object of a single or small-scale production, creation of which is necessary to implement a range of production and technological tasks.

Therefore, today, the urgent importance is the task of developing the scientific bases for organizing small-scale production of universal and specialized underwater MRTs under the conditions of ensuring their competitiveness in the domestic markets of manufacturing countries and in the international robotics markets.

\section{Life cycle and structure of the creation process operations of marine robotics tools (equipment)}

The project of creating marine robotics tools (MRT) leads to the emergence of a unique product. Despite the fact that there may be repetitive (recurring) elements present in the project results, their presence does not violate the fundamental work uniqueness for each product. The current operating activities tend to be a recurring process with definite results, as they are carried out in accordance with the existing technologies. Due to the uniqueness of the MRT, uncertainty is allowed with respect to each type of product.

The MRT creation features are most clearly manifested in their life cycle (LC) structure, namely in duration and cost. At the same time, a significant part of the total costs during the life cycle associated with the MRT creation is the cost of scientific-research (S\&R) work and research and development $(\mathrm{R} \& \mathrm{D})$ work. It should be noted that the costs of $\mathrm{S} \& \mathrm{R}$ and $R \& D$ throughout the product life cycle (PLC) are uneven. The largest volume of expenses is received at the LC pre-production stages,

5 Antonelli G., Fossen T.I., Yoerger D.R. (2008) Underwater Robotics. In: Siciliano B., Khatib O. (eds) Springer Handbook of Robotics. Springer, Berlin, Heidelberg. URL : https://doi.org/10.1007/978-3-540-30301-5_44.

6 Створення універсальних транспортних суден i засобів океанотехніки : монографія / С.С. Рижков, В.С. Блінцов, Г.В. Сгоров, Ю.Д. Жуков, В.Ф. Квасницький, К.В. Кошкін, І.В. Крівцун, В.О. Некрасов, В.В. Севрюков, Ю.В. Солоніченко; за ред. С.С. Рижкова. Миколаїв : Видавництво НУК, 2011. 340 с.

7 Tuton Mallick, Juliana Shetara. Design and construction of an underwater robot. Conference Paper September 2017. DOI: 10.1109/ICAEE.2017.8255367. 
and as the serial production is mastered and the $S \& R$ and $R \& D$ on it are practically stopped (except for scientific support of production and operation, product modernization (upgrades), etc.). In addition, an enterprise can produce several types of MRTs, and part of the costs of $\mathrm{S} \& \mathrm{R}$ and $\mathrm{R} \& \mathrm{D}$ work can be common (generic), which gives rise to the task of distributing costs between different types of MRTs.

The MRT LC stages sequence as high-tech production products is presented in Fig. 1.

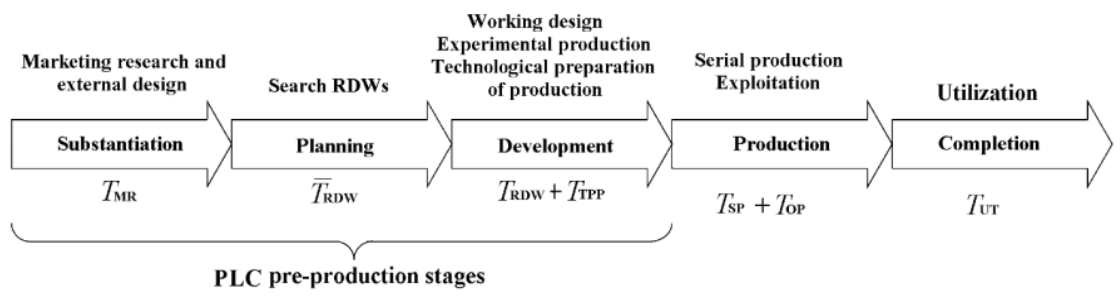

Fig. 1. MRT life cycle stages

According to the widespread classification of scientific research works, which is an integral part of the MRT creation, is aimed at creating new materials, control laws, etc. As a rule, they are of considerable duration. Thus, fundamental research is not related to the MRT LC, and their duration and cost are not included in the duration and cost of PLC. The achievement of MRT ordered parameters is determined in the course of exploratory research, when specific design and technological solutions are obtained on the basis of existing fundamental scientific knowledge. On their basis, scientific and design work and technological production preparation (TPP) begin. If it is impossible to obtain the necessary characteristics in the modern development of science and technology, then you will have to revert to the stage of marketing research and project justification (as well as set new tasks for fundamental science).

The MRT project creation life cycle, the content of which is aimed at the creation and subsequent support of the product during its life cycle, is divided into project phases. At the same time, different design phases of the project life cycle (PJLC) can be performed simultaneously ${ }^{8}$. Currently, there is no universal approach to the formation of an ideal project structure. Analyzing the peculiarities of the PLC stages formation

8 Руководство к Своду знаний по управлению проектами (Руководство PMBOK®). Шестое издание ISBN: 978-5-9693-0402-4. 
and the rational compliance with the PJLC stages, it is possible to form the MRT project creation phases.

The structure of the MRT project creation phases is formed on the basis of the accepted method of project implementation and is related to its limitations. Each project stage is initiated by defining the requirements and expected results, as well as assessing the relevance of its implementation, clarifying previously accepted assumptions, considering the identified risks and assessing in detail the content of the processes. Each stage of the project is completed by analyzing and accepting the results, identifying and correcting errors, evaluating the implementation of the results obtained and compliance with their requirements.

The work on the MRT project implementation can be divided into the following phases (Fig. 2):

- conceptual;

- commercial (price) proposal development;

- design;

- production;

- object delivery and project completion.

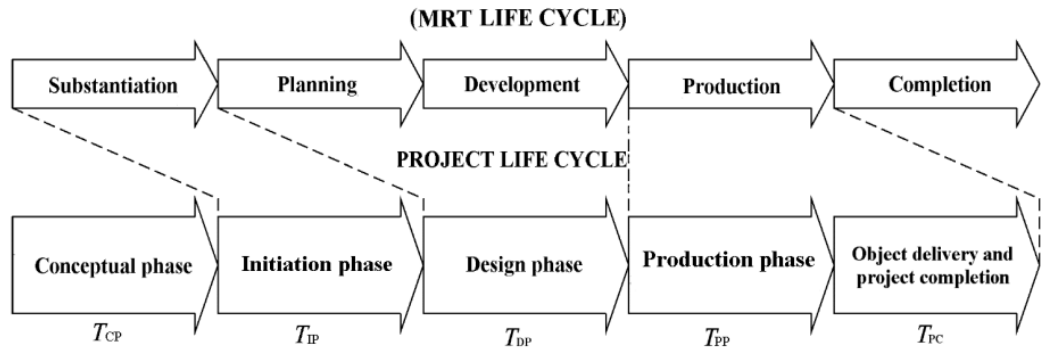

Fig. 2. Scheme of MRT project creation life cycle in the MRT life cycle context

To effectively organize the work on MRT creation, it is necessary to determine the product components.

A typical MRT (Figure. 3) includes the following elements:

- underwater vehicle (UV);

- cable winch $(\mathrm{CW})$

- control system (CS);

- attachable equipments (AE);

- engineering systems (ES). 


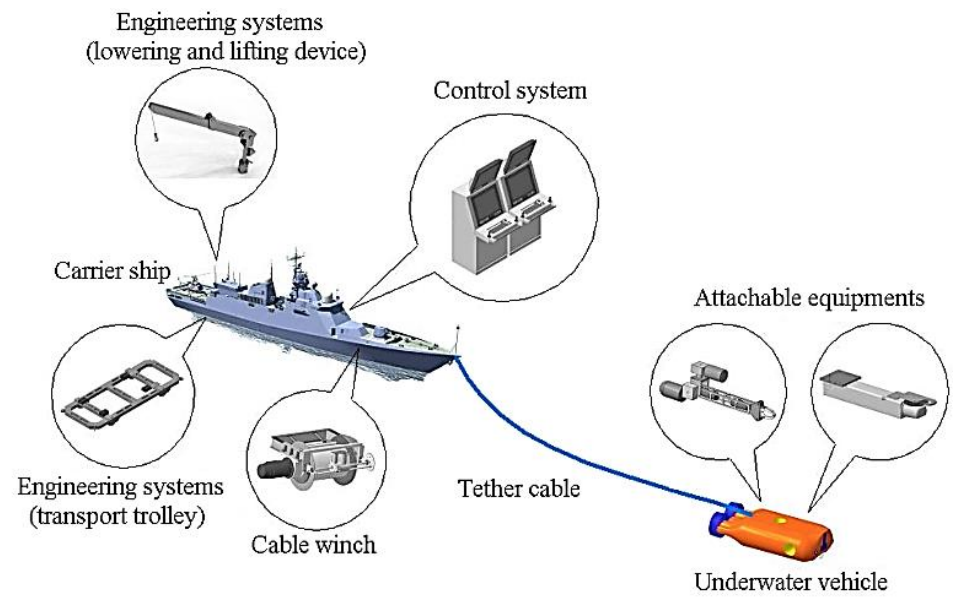

Fig. 3. Components of a typical MRT

Researches have shown that the most effective is the mixed decomposition of the MRT project creation (Fig. 4), in which it is possible to flexibly manage the project works, taking into account both mastered and new processes of creating science-intensive underwater products 9 .

Mixed decomposition (breakdown) is performed in the following sequence:

- the main elements of the project are determined;

- the science-intensive elements of the project, the implementation of which requires the solution of applied research problems are highlighted;

- the conditions for the sufficiency of the detailing of certain elements are determined;

- specific elements of the project are detailed;

- the decomposition of elements (work) into components is carried out and their sufficiency and total number are determined;

- technical tasks for the development of individual elements of the marine complex are being adjusted;

- decisions are made to complete the decomposition of project tasks.

9 Бабкін, Г.В. Структурна модель предметної області проекту створення морських комплексів для знешкодження підводних потенційно небезпечних об’єктів. 3б. наук. праць НУК. Миколаїв, 2007. № 2(413). С. 162-168. 


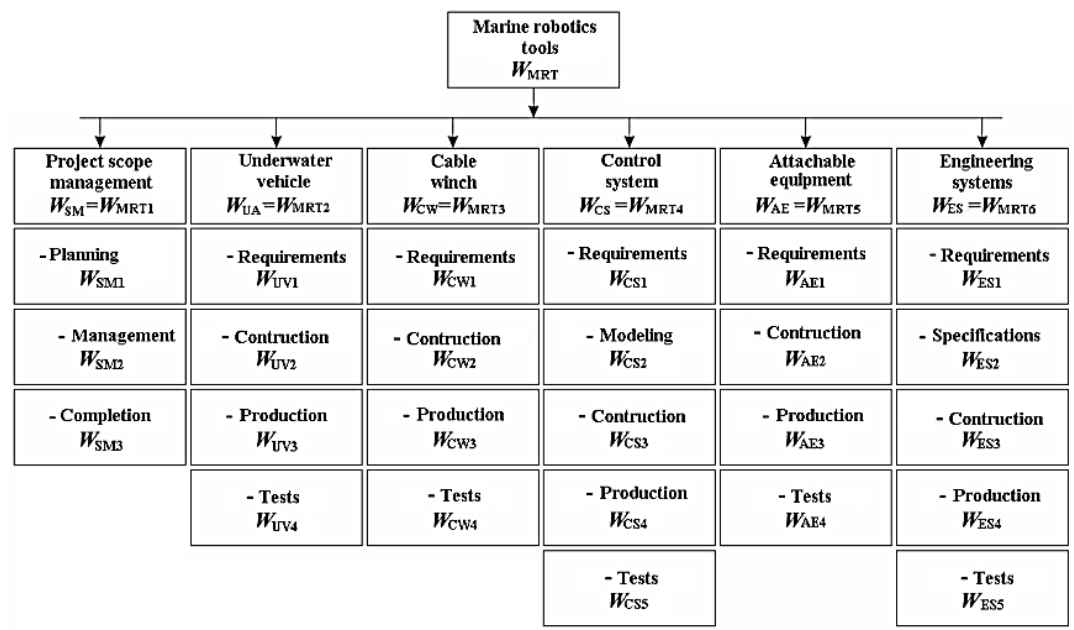

Fig. 4. Project work structure on MRT creation

Total work scope on the MRT creation

$$
\mathrm{W}_{\text {MRT }}=\sum_{\mathrm{i}} \varepsilon_{\mathrm{i}} \mathrm{W}_{\text {MRTi }}=\sum_{\mathrm{i}} \varepsilon_{\mathrm{i}} \sum_{\mathrm{j}} \mathrm{W}_{\text {MRTij }},
$$

where $\varepsilon_{i}$ - weight coefficients that determine the contribution of the ith component of the project;

$\sum_{\mathrm{j}} \mathrm{W}_{\mathrm{MRTij}}$ - the project work scope on the MRT creation, which is determined by:

$W_{\mathrm{MRT} 1}=\sum_{j} W_{\mathrm{SM} j}-$ work scope directly related to project management;

$W_{\mathrm{MRT} 2}=\sum_{j} W_{\mathrm{UV} j}-$ the work scope associated with the creation of the UV;

$W_{\mathrm{MRT3}}=\sum_{j} W_{\mathrm{CW}_{j}}-$ the work scope associated with the creation of the $\mathrm{CW}$;

$$
\begin{aligned}
& W_{\mathrm{MRT} 4}=\sum_{j} W_{\mathrm{CS} j}-\text { the work scope associated with the creation of the CS; } \\
& W_{\mathrm{MRT5}}=\sum_{j} W_{\mathrm{AE} j}-\text { the work scope associated with the creation of a AE; } \\
& W_{\mathrm{MRT} 6}=\sum_{j} W_{\mathrm{ES} j}-\text { the work scope associated with the creation of ES. }
\end{aligned}
$$


The first step in developing the work schematic structure is to determine the MRT structural composition. In accordance with the general rules of project decomposition, we break it down into structural elements that are smaller in size and more manageable.

The basis for constructing a MRT project structural model is the results of preliminary researches and analysis. At the project initial stage, based on the initial MRT creation task, we develop and substantiate its application technology.

Based on the results of the world practice of design, construction and operation of MRT, the description and justification of the standard-size series of underwater equipment is carried out, which, taking into account the developed technology, is the basis for the development and justification of the architectural-constructive type of MRT components.

Based on the results of the development of the MRT structural model, a complete list of the parts (objects) which are in its composition and which need to be developed is compiled. This information and experience from previous work are the basic data for the model development.

The experience of the authors, obtained in the creation of a number of prototypes of marine technology, showed that the traditional approach to work planning has significant shortcomings:

1) loss of time and material resources due to the implementation of the same type of work and the creation of units with the same technical characteristics;

2) the created MRTs have low "flexibility" - they have no reserves for modernization (upgrading) or rapid change in their technical characteristics.

These deficiencies can be eliminated by using, for the MRT creation, the modular principle of construction and the further formation of the elements of the organizational structure not by the objects of creation, but by technical directions of activity. (Fig. 5) ${ }^{10}$

Analysis of the developed MRT structural model shows that it is far from the classical tree-like structure. The reason for this lies in the use of a modular principle in the design of complex elements, when the same type of systems is used in all complex component elements (Table 1).

\footnotetext{
${ }^{10}$ Бушуев С.Д. Управление проектами: Основы профессиональных знаний и система оценки компетентности проектных менеджеров ; Украинская ассоциация управления проектами. Київ : ІРІДІУМ, 2006. 208 с.: табл. (National Competence Baseline, NCB UA Version 3.0).
} 
In our case, the basic structure of the $W_{\mathrm{MRT}}$ project contains $\mathrm{UV}, \mathrm{CW}$ with TC, CS, AE and ES:

$$
W_{\mathrm{MRT}}=\left\{W_{\mathrm{UV}}, W_{\mathrm{CW}}, W_{\mathrm{CS}}, W_{\mathrm{AE}}, W_{\mathrm{ES}}\right\} .
$$

In turn, the work scope required for each complex major system depends on the number of the complex systems that are included in its composition. For a vehicle-robot, it is:

$W_{\mathrm{UV}}=\left\{W_{\mathrm{PSC}}, W_{\mathrm{CTIU}}, W_{\mathrm{TVCD}}, W_{\mathrm{CF}}, W_{\mathrm{OEC}}, W_{\mathrm{ELS}}, W_{\mathrm{TVC}}, W_{\mathrm{UL}}, W_{\mathrm{BU}}\right\}$,

where $W_{\mathrm{PSC}}-$ work on the propulsion and steering complex (PSC);

$W_{\text {CTIU }}$ - work on the CT input unit;

$W_{\mathrm{TVCD}}$ - work on the TV complex drive;

$W_{\mathrm{CF}}-$ work on the carrier frame;

$W_{\mathrm{OEC}}-$ work on outboard electronic commutation;

$W_{\text {ELS }}$ - work on electronic systems;

$W_{\mathrm{TVC}}-$ work on the TV complex;

$W_{\mathrm{UL}}-$ work on the underwater lighting system:

$W_{\mathrm{BU}}-$ work on buoyancy units.

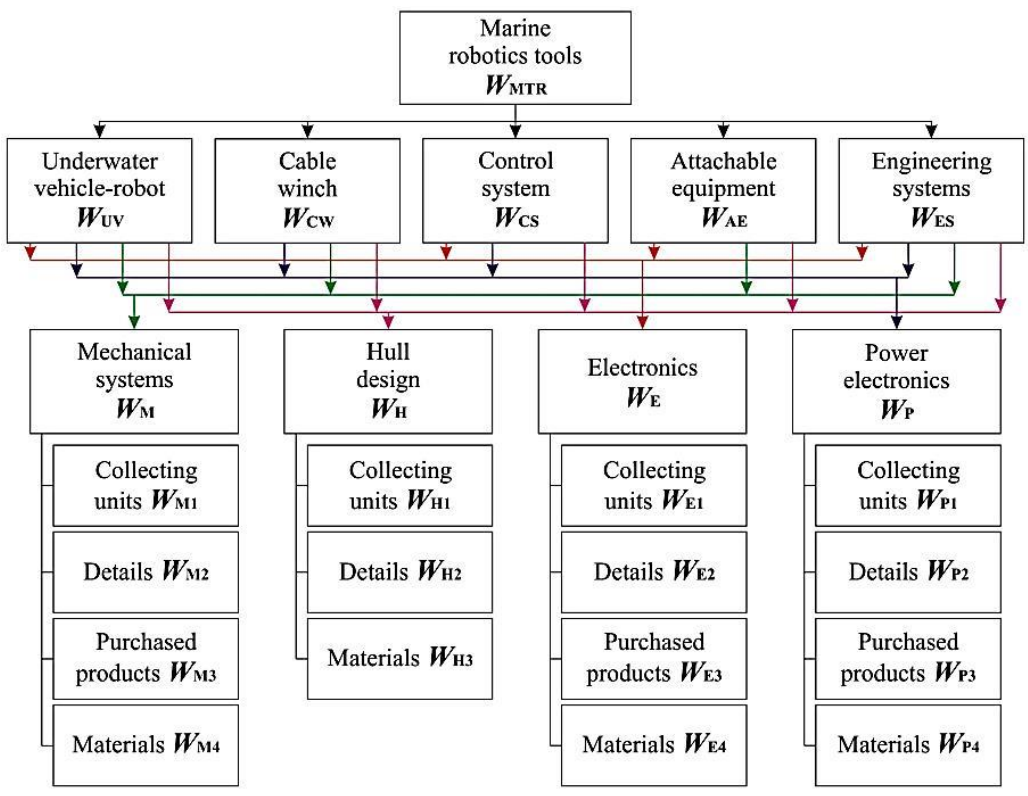

Fig. 5. The project structural model target tree 
Application of systems in various types of MRT

\begin{tabular}{|c|c|c|c|c|c|c|c|c|}
\hline \multirow{3}{*}{ MRT typical systems } & \multicolumn{8}{|c|}{ Types of MRT } \\
\hline & \multicolumn{2}{|c|}{ towed } & \multicolumn{2}{|c|}{$\begin{array}{c}\text { self- } \\
\text { propelled } \\
\text { tethered }\end{array}$} & \multicolumn{2}{|c|}{$\begin{array}{l}\text { lowerable } \\
\text { tethered }\end{array}$} & \multicolumn{2}{|c|}{ autonomous } \\
\hline & $\stackrel{\underbrace{00}_{00}}{=}$ & 巳一 & $\stackrel{\vec{E}}{.00}$ & 胥 & 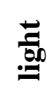 & 遈 & $\stackrel{\vec{E}}{=0}$ & 胥 \\
\hline \multicolumn{9}{|c|}{ 1. Mechanical systems } \\
\hline Underwater vehicle-robot & + & + & + & + & + & + & + & + \\
\hline $\begin{array}{l}\text { Propulsion and steering } \\
\text { complex }\end{array}$ & & & + & + & & & + & + \\
\hline Steering complex & + & + & & & & & + & + \\
\hline Video complex turnaround & + & + & + & + & + & + & + & + \\
\hline Cable winch & + & + & + & + & + & + & & \\
\hline Attachable equipment & & & & + & & & & + \\
\hline Engineering systems & + & + & + & + & + & + & + & + \\
\hline \multicolumn{9}{|c|}{ 2. Hull designs (structures) } \\
\hline Underwater vehicle-robot & + & + & + & + & + & + & + & + \\
\hline Cable winch & + & + & + & + & + & + & & \\
\hline Control system & + & + & + & + & + & + & & \\
\hline Attachable equipment & & & & + & & & & + \\
\hline Engineering systems & + & + & + & + & + & + & + & + \\
\hline \multicolumn{9}{|c|}{ 3. Electronics } \\
\hline Underwater vehicle-robot & + & + & + & + & + & + & + & + \\
\hline Navigation system (complex) & + & + & + & + & & & + & + \\
\hline Hydroacoustic complex & + & + & + & + & & & + & + \\
\hline Video complex & + & + & + & + & + & + & + & + \\
\hline Information exchange & + & + & + & + & + & + & & \\
\hline Control system & + & + & + & + & + & + & & \\
\hline Attachable equipment & & & & + & & & & + \\
\hline Engineering systems & + & + & + & + & + & + & & \\
\hline \multicolumn{9}{|c|}{ 4. Energy electronics } \\
\hline Underwater vehicle-robot & + & + & + & + & + & + & + & + \\
\hline Control system of PSC & + & + & + & + & & & + & + \\
\hline Accumulators & & & & & + & & + & + \\
\hline Cable winch & + & + & + & + & + & + & & \\
\hline Control system & + & + & + & + & & & + & + \\
\hline Information exchange & + & + & + & + & + & + & & \\
\hline
\end{tabular}


For cable winches:

$$
W_{\mathrm{CW}}=\left\{W_{\mathrm{TC}}, W_{\mathrm{CLD}}, W_{\mathrm{CTN}}, W_{\mathrm{CDD}}, W_{\mathrm{WCF}}, W_{\mathrm{WOEC}}, W_{\mathrm{WES}}\right\},
$$

where $W_{\mathrm{TC}}$ - work on TC;

$W_{\mathrm{CLD}}-$ work on the cable layer drive;

$W_{\text {CTN }}-$ work on the current transfer node;

$W_{\mathrm{CDD}}-$ work on the cable drum drive;

$W_{\mathrm{WCF}}-$ work on a winch carrier frame;

$W_{\text {WOEC }}$ - the winch outboard electronic commutation;

$W_{\text {WES }}$ - work on winch electronic systems.

For the control system:

$$
W_{\mathrm{CS}}=\left\{W_{\mathrm{CPD}}, W_{\mathrm{CPSD}}, W_{\mathrm{ES}}, W_{\mathrm{CPSS}}\right\},
$$

where $W_{\mathrm{CPD}}$ - work on control panel design;

$W_{\mathrm{CPSD}}$ - work on complex power system design;

$W_{\mathrm{ES}}-$ work on electronic systems;

$W_{\text {CPSS }}$ - work on the complex power supply system.

For engineering systems:

$$
W_{\mathrm{ES}}=\left\{W_{\mathrm{PSS}}, W_{\mathrm{LLD}}, W_{\mathrm{CoS}}, W_{\mathrm{SNS}}, W_{\mathrm{UNS}}\right\},
$$

where $W_{\mathrm{PSS}}$ - work on power supply system;

$W_{\mathrm{LLD}}$ - work on the launching and lifting device;

$W_{\text {CoS }}$ - work on communication system;

$W_{\text {SNS }}$-work on surface navigation system;

$W_{\text {UNS }}$ - work on underwater navigation system.

Work on each of the systems making up the MRT, can be found as the sum:

$$
W=\sum_{i=1}^{n} W_{i},
$$

where $W_{i}$ is the work on a device that is included in the system;

$n$ is the total number of devices included in the system.

Similarly, using the expression (1.3), work on nodes and assembly units are defined:

$$
\begin{aligned}
& W_{i}=\sum_{n=1}^{m} W_{n}, \\
& W_{n}=\sum_{m=1}^{k} W_{m},
\end{aligned}
$$




$$
W_{m}=\sum_{k=1}^{d} W_{k},
$$

where $W_{i}-$ work on the system device;

$W_{n}$ - work on the device nodes;

$W_{m}$ - work on the assembly unit (component), which is included in the node;

$W_{k}$ - work on the part included in the assembly unit;

$m$ - total number of nodes in the device;

$k$ - total number of assembly units in the node;

$d$ - total number of parts included in the assembly unit.

Considering the fact that electric drives are used in the vehicle-robot both in the propulsion-steering device and in the television complex, and in the cable winch - in the cable layer drive and in the cable drum drive, taking into account expressions (1.1), (1.2) and (1.3), we obtain:

$$
W_{\mathrm{DR}}=W_{\mathrm{PSC}} \bigcap W_{T V C D} \bigcap W_{\mathrm{CLD}} \bigcap W_{\mathrm{CDD}},
$$

where $W_{\mathrm{DR}}$ - work on marine complex electric drives.

Similarly, the work on the control systems and telemetry of the basic elements of the marine complex can expressed as

$$
W_{\mathrm{EL}}=W_{\mathrm{ELS}} \bigcap W_{\mathrm{WES}} \bigcap W_{\mathrm{ES}},
$$

where $W_{\mathrm{EL}}$ - work on marine complex electronic systems.

Work on the outboard electronic commutation:

$$
W_{\mathrm{EC}}=W_{\mathrm{OEC}} \bigcap W_{\mathrm{WOEC}},
$$

where $W_{\mathrm{EC}}$ - work on of marine complex electronic commutation.

Each of MRT major systems is a finished (complete) technical product and is universal within the framework of one class of technical facilities, that is, it can be used as part of any product of this class or series. In addition, the use of similar components and mechanisms in all the elements of the complex, in accordance with the modular construction principle, can significantly increase the survivability and maintainability of the nodes, as well as significantly reduce time and labor for design, construction and repair and restoration work in the event of emergencies during the operation of the complex (system). This 
circumstance is relevant when performing operations at a considerable distance from the repair bases ${ }^{11}$.

Thus, the system of relations (1.4-1.6) forms the basis for determining the value (cost) of the project design work for creation.

Based on the results of the development and analysis of the structural model, the MRT elements are divided into three categories. The first category includes those elements and components that can be used from previous projects. The second category refers to those elements and components, which can be borrowed from previous projects, but for the new project it is required to conduct $R \& D$ work. And in the third category identifies those elements for the production of which $S \& R$ work will be necessary to be conducted.

\section{Organization of project works and production}

The first step in implementing the R\&D work for MRT creation is to determine the project decomposition top level. This level will be the main basic objects, MRT components, the list of which is determined by the technical specifications:

- underwater vehicle;

- attachable equipment;

- cable winch;

- tether cable;

- control system;

- transportation trolley;

- a set of spare equipment;

- operational documentation;

- assembly components (connection blocks).

For the realization of each object, at each $R \& D$ work stage, it is necessary to perform a certain list of operations and tasks during its implementation (Table 2).

The developed plan should be checked for feasibility and optimality. In practice, such management is expressed in checking the sufficiency and necessity of labor and material resources for implementation.

11 Блинцов В.С. Современные проблемы создания электрооборудования и автоматики подводных аппаратов. Начіональний аерокосмічний університет ім. М.Є. Жуковського «Харківський авіаиійний інститут». Радіоелектронні $i$ комп'ютерні системи: науково-технічний журнал. Харків : НАУ ХАУ, 2007. № 5(24). С. 90-98. 


\section{List of work}

\begin{tabular}{|l|l|}
\hline \multicolumn{1}{|c|}{ (R\&D) work stages } & \multicolumn{1}{|c|}{ Main tasks and work scope } \\
\hline Schematic (draft) design & $\begin{array}{l}\text { Development of fundamental technical solutions: } \\
\text { 1) the choice of the development elemental base; } \\
\text { 2) choice of basic technical solutions; }\end{array}$ \\
3) development of structural and functional schemes \\
of the product; \\
4) choice of main structural elements; \\
5) metrological examination of the project; \\
6) development and testing of prototype models.
\end{tabular}


The resulting schedule should also be checked for compliance with the timeframes provided for the implementation of each $S \& D$ and $R \& D$ work project. It is especially important to make sure that:

- project milestones are chosen correctly;

- project work execution periods are clearly marked and correspond to the adopted action plan;

- breakdown of works meets the requirements of the feedback principle on the project generalization and analysis;

- the work (activity) coding corresponds to the work cost breakdown.

In the future, the graphs should reflect the current work implementation status, so they should be constantly updated. The main reasons for the discrepancy between the planned schedules and the actual project implementation development are:

- the project implementation experiences constant destabilizing effects in the form of deadlines, shortages, changes in financing conditions, climatic influences, etc. This means that it is nearly impossible to predict all these changes when plotting graphs;

- the model underlying the control basis, during construction, was significantly influenced by the developer subjective factor. That is, work schedules are subjective in origin;

- the presence of many technologically admissible options of work execution.

Work schedules may be revised during the project course. One or more of the following characteristics may vary:

- sequence of work performance;

- the work execution duration;

- resources used in the work performance implementation;

- work execution period.

Typical planning mistakes include:

- setting the wrong project goals;

- incomplete initial data for planning;

- lack of consideration of previous experience;

- lack of information on the availability of resources;

- use only planners;

- low degree of coordination;

- lack of motivation;

- unnecessary details or detail enlargement;

- lack of tracking of the implementation of plans.

The MRT creation process is not only qualitative, but also quantitative. The number of options for achieving the goal is increased 
due to the use of various technical solutions or their combination. The necessary characteristics of the created MRT, which determine the effectiveness of its application, can be obtained using various materials, structures, equipment, etc.

The use of complex components in MRT creation, an increase in the cost of $S \& R, R \& D$ and project work puts the MRT creation project on a par with the products of the shipbuilding and aviation industries.

During the project implementation, the problem of multivariate solutions constantly arises, which differ in characteristics and cost. A feasibility study is needed to select the best option that will meet the accepted criteria. The need for economic substantiation and its nature are necessary at every project implementation stage, namely:

- draft (sketch) design, during which the design developmental work of MRT optimal version is realized, the drawings of the main components and the general view and parameters of the product are specified;

- a technical project in which the work necessary to meet the MRT requirements and allows to get a complete picture of its design are carried out, assess its compliance with the requirements of the tactical and technical specification (TTS) or the technical specification (TS), the manufacturability, the degree of production (manufacturing) complexity, packaging methods, transport and installation possibilities at the location of use, flexibility in operation and maintainability;

- working design documentation for the prototype production, developed in accordance with the requirements of the TTS (TS);

- production of a prototype, on which a prototype is manufactured to determine its conformity to the requirements of the TTS/TS and the possibility of providing for official tests (trials);

- prototype official (state) testing in accordance with the developed programs and methods to verify the compliance of the product characteristics with the TTS/TS requirements;

- approval of working design documentation for the organization of serial production, where the coordination and approval of a set of design documentation takes place and preparation for the establishment of mass production.

In the course of justification, each product can be described by a set of characteristics that determine the properties of the MRT as a whole, its operational data and other technical characteristics, the totality of which determines the appearance of the project object. 
Solving the problem of MRT mass production requires a systematic approach using new robotic underwater technologies and project management methodology, requires investments, attracting a certain amount of financial, material and human resources to obtain the planned result.

Taking into account the need for MRT serial production, prerequisites are created for the creation of a project-oriented enterprise, which is distinguished by uniqueness, focus on the final result, life cycle, time and resource constraints, etc., which will engage in research and production in this sphere. The development and production of new MRT samples will significantly increase the efficiency of underwater technical works, as well as reduce their cost.

The basis for the emergence and functioning of a certain type of organizational management structure in the enterprise, as well as the basis for increasing productivity is the horizontal distribution of labor, in which the entire work scope is divided into components ${ }^{12}$.

The simplest approach to forming divisions is quantitative. The division is created on the basis of the number of personnel required to complete the assigned task, taking into account its effective management possibility.

The technological approach forms a separate division and is used at the lower level of production organizations. It implies that the basis for the creation of subdivisions or sections is an independent type of activity, a technological process or its relatively independent element.

In scientific institutions or educational institutions, divisions can be created on the basis of a professional approach, when in one division, people who have the same or similar specialties and are engaged in common issues are united.

Large enterprises and their associations with many thousands of employees have functional or divisional structures that fall under the socalled "rigid" category.

\section{CONCLUSIONS}

The paper describes the current scientific and applied task of developing and improving methods and models of project management for the serial creation of marine robotics.

12 Тернер Дж. Родни Руководство по проектно-ориентированному управлению ; перевод с англ. В.И. Воропаева. Москва : Издательский дом Гребенникова, 2007. 552 с. 
On the basis of the analyzed life cycles of the product and the project of creation of means of marine robotics the hierarchical structure of works is formed.

The analysis of the life cycle of the project of creation of means of marine robotics, in particular, the analysis of their duration and cost is executed. The analysis of features of processes of creation of means of sea robotics is carried out, processes and features of planning of such projects are analyzed.

The model of project cost management as a theoretical basis for improving the efficiency of management of the processes of creating marine robotics tools is considered.

A reasonable distribution of functions in the areas of creation of components of marine robotics of different types, which is the basis for effective planning of work on their design and construction. As a result, the upper level of decomposition of such works is formed and typical errors in their planning are indicated.

The results of research have been tested and shown their effectiveness in a number of projects to create marine robotics.

The practical significance of the results of the study is to use the proposed models:

- when creating a marine research laboratory on the basis of the research vessel "Delta" of admiral Makarov National University of Shipbuilding (NUOS, Ukraine);

- when creating prototypes of ZMR in the research institute of underwater equipment of NUOS and when conducting sea expeditions;

- when planning the robotic support of sea underwater expeditions of the organizations of the State Emergency Service of Ukraine;

- in the formation of plans for further research work of the Research Institute of Underwater Technology NUOS;

- in the formation of curricula for training specialists in this area of research.

\section{SUMMARY}

The paper considers an urgent scientific task - to increase the efficiency of creating marine robotics. The analysis of the existing methods, models and mechanisms of the organization of works on creation of means of sea robotics is executed. Peculiarities of design works on creation of means of marine robotics are investigated. The structure of the marine robotics tool as an object of project management is considered. The issues of organization of 
design and construction works are considered. The description of features of separate stages of design works is carried out. Preconditions for the formation of a specialized enterprise for the creation of marine robotics have been formed.

\section{REFERENCES}

1. How much of the ocean have we explored? URL : https://oceanservice.noaa.gov/facts/exploration.html.

2. Ocean exploration. Highlights of National Academies Reports. Ocean science series. The National Academies. Advisers to the Nation on Science, Engineering and Medicine. URL : https://www.nap.edu/resource/11902/exploration_final.pdf.

3. Исследования Мирового океана как шаг на пути к устойчивому развитию человечества. URL : https://rg.ru/2020/07/28/ issledovaniia-mirovogo-okeana-kak-shag-na-puti-k-razvitiiuchelovechestva.html.

4. Future Needs in Deep Submergence Science (2004). Occupied and Unoccupied Vehicles in Basic Ocean Research. The National Academies Press. Washington, D.C. URL : https://www.nap.edu/catalog/ 10854/future-needs-in-deep-submergence-science-occupied-andunoccupied-vehicles.

5. Antonelli G., Fossen T.I., Yoerger D.R. (2008) Underwater Robotics. In: Siciliano B., Khatib O. (eds) Springer Handbook of Robotics. Springer, Berlin, Heidelberg. URL : https://doi.org/10.1007/ 978-3-540-30301-5_44.

6. Створення універсальних транспортних суден i засобів океанотехніки : монографія / С.С. Рижков, В.С. Блінцов, Г.В. Сгоров та ін. ; за ред. С.С. Рижкова. Миколаї в: Видавництво НУК, 2011. 340 с.

7. Tuton Mallick, Juliana Shetara. Design and construction of an underwater robot. Conference Paper September 2017. DOI: 10.1109/ICAEE.2017.8255367.

8. Руководство к Своду знаний по управлению проектами (Руководство РМВОК®). Шестое издание ISBN: 978-5-9693-0402-4.

9. Бабкін Г.В. Структурна модель предметної області проекту створення морських комплексів для знешкодження підводних потенційно небезпечних об'єктів. Зб. наук. праџьь НУК. Миколаїв, 2007. № 2(413). С. 162-168.

10. Бушуев С.Д. Управление проектами: Основы профессиональных знаний и система оценки компетентности 
проектных менеджеров / Украинская ассоциация управления проектами. Київ : ІРІДІУМ, 2006. 208 с.: табл. (National Competence Baseline, NCB UA Version 3.0).

11. Блинцов В.С. Современные проблемы создания электрооборудования и автоматики подводных аппаратов. Національний аерокосмічний університет ім. М.С. Жуковського "Харківський авіаційний інститут». Радіоелектронні $i$ комп'ютерні системи: науково-технічний журнал. Харків : НАУ ХАУ, 2007. № 5(24). С. 90-98.

12. Тернер, Дж. Родни Руководство по проектноориентированному управлению ; перевод с англ В.И. Воропаева. Москва : Издательский дом Гребенникова, 2007. 552 с.

\title{
Information about the authors:
} Blintsov V. S., Doctor of Technical Sciences, Professor, Vice-Rector for Scientific Work Admiral Makarov National University of Shipbuilding 9, Heroes of Ukraine avenue, Mykolaiv, 54025, Ukraine

\author{
Babkin G. V., \\ $\mathrm{PhD}$ in Engineering Science, \\ Associate Professor at the Department of Electrical Engineering of Ship \\ and Robotic Systems \\ Admiral Makarov National University of Shipbuilding \\ 9, Heroes of Ukraine avenue, Mykolaiv, 54025, Ukraine
}

